\title{
Entrevista a la professora Nivedita Mani
}

Nivedita Mani és professora de Psicologia del Llenguatge a la Georg-AugustUniversität Göttingen. Va rebre un DPhil (doctorat en Lingüística) de la Universitat d'Oxford el 2006. Després de dos postdoctorats, el primer a St Hugh's College, Oxford, i el segon a la University College London amb una beca de l'Acadèmia Britànica per examinar la preparació fonològica en la infància, finalment es va traslladar a Göttingen el gener de 2010 per establir el Grup de Recerca en Psicologia del Llenguatge i el laboratori de llenguatge infantil associat, WortSchatzInsel. És la investigadora principal de diversos projectes finançats per la Fundació d'Investigació Alemanya (i l'Acadèmia Britànica durant la seva estada al Regne Unit). Ha publicat extensament en el seu camp, incloent el recent volum coeditat Early Word Learning ${ }^{1}$. El seu treball examina els factors subjacents a l'aprenentatge de paraules i al reconeixement en nens petits i considera que l'aprenentatge de paraules és el resultat d'una interacció dinàmica i mútua entre l'entorn i l'alumne, amb especial atenció a l'alumne i al que sap, al que li interessa i, més recentment, a la seva motivació per aprendre.

http://www.uni-goettingen.de/en/356789.html

Ens vam conèixer fa poc al taller WILD 2019 a Potsdam, on vas oferir una xerrada amb un títol suggeridor: per què els nens aprenen les paraules que emeten? M'agradaria parlar amb vostè sobre aquest interessant tema perquè el lector pugui fer-se una idea més clara sobre les qüestions específiques que es tracten actualment en aquest camp i la novetat del seu enfocament sobre l'aprenentatge primerenc de les paraules.

(1) La producció de la primera paraula és una fita crucial en el desenvolupament del llenguatge que s'aconsegueix generalment cap als dotze mesos d'edat. És el resultat d'un procés llarg i complex que comença diversos mesos abans i que implica desenvolupaments tant en la part de la percepció com en la de la producció. Per començar, podria descriure breument les habilitats bàsiques i els coneixements necessaris per assolir amb èxit aquesta fita crucial?

De fet, aquesta primera paraula cap als dotze mesos d'edat i totes les paraules que la segueixen són el resultat d'una sèrie de processos que han començat abans, fins i tot a l'úter, i que continuaran desenvolupant-se molt més enllà del primer any de vida. Pel que fa al llenguatge, això requereix que el nen sigui capaç de comprendre i produir els sons components associats a les paraules en el seu llenguatge, discriminar aquests sons entre si, reconèixer-los i produir-los en contextos coarticulatoris, és a dir, envoltat d'altres sons i paraules. Alhora, els nens necessiten també associar el significat d'aquestes paraules, és a dir, associar aquestes paraules a alguns referents del món real (en el cas de substantius concrets) o acumular un conjunt d'associacions per a aquestes paraules, comprendre els contextos en els quals aquestes paraules es poden utilitzar (en el cas de substantius abstractes, verbs i paraules funcionals).

Especialment en el cas dels substantius concrets, en els quals em concentro en el meu treball, els nens també necessiten aprendre a categoritzar el seu món visual per poder associar les paraules amb objectes particulars del seu entorn. Així, per exemple, en aprendre la paraula gos, els nens necessiten saber que aquesta paraula s'aplica no només al gos que tenen a casa sinó també a altres gossos que veuen de manera rutinària $\mathrm{i}$ als gossos que es troben en el futur que poden no assemblar-se al gos amb el qual van aprendre a associar aquesta paraula per primera vegada. Per tant, un grau de desenvolupament cognitiu en termes de categorització, generalització, discriminació i

${ }^{1}$ WESTERMANN, Gert; MANI, Nivedita (ed.). Early word learning. Routledge, 2017. 
identificació d'objectes i sons en el seu entorn és un prerequisit en el camí cap a aquesta primera paraula.

(2) L'aprenentatge de paraules s'ha de considerar com una cosa més que una simple associació o mapatge d'etiquetes i objectes. L'èxit de l'aprenentatge de paraules implica superar una sèrie de problemes que solen ocórrer en els contextos d'aprenentatge de paraules. Pot destacar quins són alguns d'aquests problemes per al jove estudiant ingenu?

En efecte. La situació que he descrit anteriorment - per complicada que sembli- és l'escenari ideal. Els nadons i els nens petits s'enfronten a una sèrie de reptes addicionals quan es tracta d'aprendre paraules. Per exemple, els nadons estan exposats a una varietat d'aportacions de diferents persones en diferents contextos, amb diferents accents en diferents estats de salut emocional i física. Sabem que tots aquests factors condueixen a diferències subtils però importants en les propietats físiques de les paraules que els nens escolten diàriament. Els nens necessiten aprendre quines d'aquestes diferències es poden ignorar i quines són funcionalment rellevants; quines es podrien retenir per facilitar el reconeixement posterior de les paraules tot i no ser funcionalment rellevants, per exemple, retenint informació sobre l'accent d'un parlant freqüent tot i que aquestes diferències accentuals necessitin ignorar-se en reconèixer una paraula.

(3) Hi ha prejudicis que ajudin a explicar aquest aprenentatge ràpid i reeixit de paraules dels nens tot i les dificultats esmentades anteriorment?

Depèn del que entenguis per prejudicis, quan i com creguis que arriben a existir i a qui l'hi preguntis. Si m'ho preguntes a mi, definitivament hi ha certes predisposicions cognitives que els nens desenvolupen en base a la seva experiència amb el món, i aquestes predisposicions poden influenciar l'atenció que dediquen a diferents fonts, de tal manera que amb el temps, els nens aprenen a atendre fonts rellevants d'informació en el seu entorn $\mathrm{i}$ això els ajuda a filtrar les distraccions.

(4) Una mirada més propera a les paraules que cada nen aprèn revela una gran variabilitat. La font de la variabilitat depèn principalment de les característiques de les entrades (quantitat i qualitat), com s'ha considerat tradicionalment?

Durant molt de temps es va pensar que la principal font de variabilitat en el nombre i tipus de paraules conegudes per cada nen en diferents edats era la qualitat i quantitat de l'input que rebien els nens, és a dir, el que aquests escolten i veuen determinarà quines paraules aprendran. De fet, és cert que el llenguatge és un coneixement adquirit. Els nens necessiten sentir i veure el llenguatge que s'utilitza per aprendre la llengua.

No obstant això, més recentment, els estudis suggereixen que els nens no només són receptors passius de les aportacions que reben, sinó que també poden dirigir activament el seu aprenentatge atenent més a determinats tipus d'aportacions que a altres. Això es basa en estudis que mostren que els nens obtenen regularment informació de les persones sobre objectes que els interessen per saber més, que aprenen i retenen informació de certs tipus de persones més que d'altres, que les diferències en el grau d'aprenentatge autoexploratori dels nens es correlacionen amb la mida posterior del vocabulari, que en general són selectius pel que fa a qui aprenen, què aprenen i quan obtenen i retenen nova informació. Això suggereix que hi ha un component actiu dirigit pel nen en l'aprenentatge que pot contribuir igualment a la variabilitat en les paraules que aprenen.

(5) La seva perspectiva conceptual sobre l'aprenentatge primerenc de paraules destaca el paper "actiu" que els nens exerceixen en aquesta tasca: tant el coneixement com els interessos dels nens estarien impulsant l'aprenentatge primerenc de paraules. Pots descriure més explícitament aquesta interessant perspectiva? 
Quins factors poden influir en aquest aprenentatge actiu en els nens... Com s'ha assenyalat anteriorment, si bé continua sent cert que les aportacions influeixen en el nombre i el tipus de paraules que els nens aprenen, els treballs recents suggereixen que pot haver-hi una sèrie d'altres factors en joc que poden esbiaixar no només el que els nens aprenen, sinó també potencialment les aportacions que reben.

Això inclou, per exemple, el coneixement que cada nen té. Per tant, hi ha diferències en la quantitat d'informació que tenen sobre paraules concretes i tipus concrets de paraules i el que saben sobre paraules concretes dona forma a les paraules que és probable que aprenguin. Per exemple, els nens que ja coneixen molts noms d'animals probablement trobaran més fàcil aprendre un nom nou d'animal ja que tenen molt coneixement sobre aquesta categoria que poden aprofitar per aprendre una nova paraula. Així, per exemple, aquest nen podria saber que els animals són animats, que típicament tenen ulls i sovint tenen nassos, orelles, boca i potes i que es mouen. Ara bé, quan un nen està familiaritzat amb més animals, llavors té més varietat d'atributs emmagatzemats pel que fa al que és un animal i té més certesa sobre els atributs que són necessaris o requerits perquè alguna cosa sigui un animal. Aquest coneixement pot facilitar que el nen categoritzi ràpidament l'estímul visual que rep -en ser presentat amb un nou animal- i aprengui l'etiqueta d'aquest objecte. Igualment, si un nen coneix moltes paraules que sonen similars entre si, per exemple, gat, rata, greix, estora, llavors pot ser més fàcil per a ell aprendre una altra paraula que soni similar a aquestes perquè té més certesa pel que fa als sons que componen aquesta paraula. En aquests casos, suggerim que els nens puguin utilitzar el coneixement que ja tenen sobre determinades paraules per aprendre'n de noves que se superposen en certes dimensions. D'aquesta manera, el coneixement dels nens pot orientar quines paraules s'aprenen i retenen en una mesura considerable.

Encara que això suggereix que les paraules que els nens ja coneixen poden influir en les paraules que probablement aprenguin, això deixa sense resposta el motiu pel qual els nens coneixen tantes paraules en categories concretes en primer lloc. Això podria estar indirectament relacionat amb les aportacions que reben o hi podria haver altres factors que influeixin en el seu coneixement del món? Suggerim que un d'aquests factors és l'interès dels nens en objectes particulars del món que els envolta. En particular, suggerim que és probable que hi hagi diferències en l'interès dels nens per determinats objectes del seu entorn; per exemple, és probable que alguns nens estiguin més interessats i fascinats pels animals, mentre que d'altres poden estar més interessats en els vehicles. Aquest interès, suggerim, pot portar-los a atendre més els objectes que els interessen i a aprendre i retenir més informació sobre aquests objectes. Per tant, un nen que està més interessat en els animals pot aprendre i retenir el nom d'un animal nou amb més facilitat que un nen que està més interessat en els vehicles.

(6) En què es diferencia aquesta perspectiva d'altres punts de vista en els quals el paper de l'entorn i, més concretament, el paper dels cuidadors té més pes?

Els enfocaments pedagògics de l'aprenentatge del llenguatge suggereixen que els nens es beneficien del fet que els cuidadors els proporcionen intuïtivament la informació òptima que necessiten per aprendre. Per tant, nosaltres i els cuidadors sabem com parlar amb els nens, de quina manera i quan parlar-los, i que l'optimització de la informació que proporcionem és fonamental per configurar l'aprenentatge. Sense descomptar la influència de les aportacions dels cuidadors en l'aprenentatge, aquesta perspectiva d'aprenentatge actiu suggereix que el que els nens saben i en el que estan interessats no només donarà forma al que els nens aprendran sinó també al tipus d'aportació que reben, sent els cuidadors sensibles a la mena de coses que els seus nens ja saben i en què estan 
interessats i proporcionant més aportacions d'aquest tipus. Així, allunyant-se de la influència unidireccional de les aportacions en l'aprenentatge dels nens, aquest enfocament suggereix que els nens poden tan influenciar com donar forma a les aportacions que reben, com també ser influenciats per aquestes aportacions.

(7) Vostè ha suggerit un vincle entre l'aprenentatge ràpid de paraules i el processament basat en recompenses (és a dir, la motivació per aprendre, per dir-ho d'una altra manera).

Aquesta és una idea suggeridora, però com podria abordar-se en la investigació sobre la infància?

En efecte. En certa manera no és una idea nova. Des Aristòtil fins a Piaget, els filòsofs i investigadors han suggerit que els nens poden estar intrínsecament motivats per aprendre. Que l'aprenentatge pot ser gratificant en si mateix. Es pot tractar d'una motivació intrínseca específica, amb nens interessats específicament en adquirir informació sobre algun aspecte particular del seu entorn, en aquest cas pot superposar més amb la seva curiositat sobre un tema concret, o pot ser una motivació intrínseca més general per aprendre, és a dir, que volen aprendre per avançar en el seu coneixement però que aquest aprenentatge no es restringeix a una àrea en particular. La curiositat sobre un tema en particular i la seva influència en l'aprenentatge es pot aprofitar examinant l'interès dels nens en diferents temes i com això modela l'aprenentatge (com s'ha descrit anteriorment). Una motivació intrínseca general per aprendre pot ser més difícil d'aprofitar. En els adults, aquests estudis han examinat la mesura que el circuit de recompensa del cervell, és a dir, l'estrat ventral, s'activa durant l'aprenentatge de la paraula dels adults. Això és més difícil en els nens petits i pot requerir tècniques menys invasives, incloent per exemple mesures conductuals de processament basat en la recompensa, com la postura corporal o la valència corporal, o mesures neurofisiològiques com la dilatació de la pupil-la o les oscil-lacions cerebrals, per examinar fins a quin punt els nens troben l'aprenentatge, i l'aprenentatge de paraules, especialment gratificant.

(8) Aquesta perspectiva és útil per entendre i explicar millor els retards en l'aprenentatge de les paraules, com per exemple els que es troben en els parlants tardans o fins i tot en els nens amb un trastorn del desenvolupament de llenguatge?

Crec que aquesta perspectiva podria ser molt útil no només per entendre els retards en l'aprenentatge de paraules sinó també per fomentar un millor aprenentatge en tals poblacions. Identificar les àrees en què els nens estan motivats per aprendre i utilitzar la seva motivació per aprendre en aquestes àrees per fomentar l'aprenentatge addicional són tècniques en què la literatura pedagògica s'ha enfocat per a molt de temps. Hi ha una considerable consciència que l'èxit escolar està estretament relacionat amb el fet que els nens s'interessin pel que s'ensenya i pel temps que perseverin en determinades tasques. Avui no hi ha raó per suposar que una motivació intrínseca similar no sigui útil per impulsar l'aprenentatge en poblacions amb trastorns del llenguatge. Igualment, hi ha la possibilitat de considerar que els nens amb dificultats de llenguatge poden ser conscients de les seves dificultats i, per tant, mostrar una menor motivació afectiva per aprendre, ja que es conceben a si mateixos com més febles en una àrea determinada. Novament, en la literatura escolar, aquesta noció d'autoconcepte dels nens ha demostrat que influeix no només en el bé que els nens aprenen, sinó també en el temps que perseveren en determinades tasques, la qual cosa comporta la possibilitat que les dificultats que tingui un nen a l'hora de dur a terme una tasca particular pugui esdevenir en dificultats en l'aprenentatge i la retenció. 